\title{
Social behaviour of wintering Great Northern Divers Gavia immer in relation to age categories
}

\author{
Ingvar Byrkjedal
}

Bergen Museum, University of Bergen, P.O. Box 7800, Allégt. 41, N-5020 Bergen, Norway

E-mail: ingvar.byrkjedal@zmb.uib.no

\begin{abstract}
Focal-animal studies of Great Northern Divers Gavia immer wintering on the coast of Jæren, SW Norway, showed social behaviour to vary over the season. Groups consisting of two adults and one or two juveniles arrived in autumn. The adults of such groups were aggressive toward neighbouring divers including other adults. In early winter juveniles as well as adults adopted a solitary and dispersed existence and adults showed aggressiveness also toward juveniles. Second winter birds were solitary throughout the winter, and they were intermediate between adults and juveniles in dominance level. Juveniles associated with two adults spent more time feeding and less time in comfort activities than the accompanying adults. The social groups containing adults and juveniles are interpreted as family groups in which parents perform prolonged parental care presumably allowing juveniles to gain experience with marine food and habitat. Some twosome adults without juvenile company are seen after arrival in autumn, and again in late winter some time before departure, suggesting that pair members might accompany one another on migration. Differences in social behaviour of birds wintering in Europe and in North America are briefly discussed.
\end{abstract}

Key words: post-migratory parental care; intraspecific aggression; winter ecology; Gaviidae

\section{INTRODUCTION}

Defending feeding and chick-rearing areas, Great Northern Divers Gavia immer are strongly territorial on their breeding grounds (Evers et al. 2010). While chicks capture insects and other invertebrate prey, their primary food of fish is provided by their parents. Great Northern Divers winter on marine coasts and shelves where their diet consists of fish and to some extent crustaceans (Evers et al. 2010). In winter they usually space out, and in one study some wintering birds were found to hold feeding territories (McIntyre 1978). Other studies have failed to record territorial behaviour in winter (Daub 1989, Ford \& Gieg 1995). None of these studies related the winter behaviour to the birds' age.

During studies of other waterfowl on the SW Norwegian coast (e.g. Byrkjedal et al. 1997) I noted that social interactions occurred between individuals of Great Northern Divers. Studies of moult and plumages, especially those of Jonsson \& Tysse (1992), greatly enhanced differentiation in field between adult, second winter and juvenile Great Northern Divers, and in a number of winters I collected data on the social behaviour of Great Northern Divers along a stretch of SW Norwegian coast, and related the behaviour to the birds' age groups. The data give new insight into the winter ecology of this species. The present paper reports the results of these studies.

\section{MATERIAL AND METHODS}

The study was done along the coast of Jæren (situated at latitude $58 \mathrm{oN}$ ), SW Norway, in the years 1996-2010. With almost no islets or skerries the coastline, about $60 \mathrm{~km}$ long, is exposed to the North Sea and consists of mostly sandy and cobbly shallow waters, colonized by kelp Laminaria spp. (Byrkjedal et al. 1997). A total of approximately 1000 Great Northern Divers, presumably from Icelandic, Greenlandic, and perhaps arctic Canadian breeding grounds, spend the winter on the Norwegian coast, mainly in exposed waters (Byrkjedal et al. 2000). Arriving in October-early November and departing in April-May, about 40-50 Great Northern Divers spend the winter dispersed along the coast of Jæren (Tysse 1981). Great Northern Divers usually dive for food in waters less than $10 \mathrm{~m}$ deep. The $10 \mathrm{~m}$ isobath along the coast of Jæren is situated about $300-900 \mathrm{~m}$ from the shore. Divers usually were closer to the shore than $500 \mathrm{~m}$.

The observations were done from the shore, either from tall sand dunes or other points that gave a good overview of the waters watched. The birds were observed through $10 x$ binoculars and a $20-45 x$ spotting scope and behavioural data recorded by focal-animal sampling (Altmann 1974). For continual observations of individual divers to be carried out for any length of time field work was undertaken in calm weather, ideally with a flat sea, 
as ripples and waves frequently would cause the birds to be lost from sight. To search the whole coast of Jæren for divers and carry out observations take several days. Often the field work was interrupted by bad weather, hence the field schedule became somewhat opportunistic. To minimize the risk of sampling the same individuals more than once during the same time period, no stretch of coast was worked more than once in any one month in any of the years. None of the birds were individually marked, however, and it is unknown to what extent the same birds were studied through a winter or between years.

Upon observation of a Great Northern Diver, the following protocol was followed: The bird was observed for half an hour, during which its location was traced on a map (scale 1:20 000), its observed behaviour (feeding, preening, loafing, locomotion, social interactions) dictated to a tape recorder or an electronic speech recorder and timed using a stopwatch or the speech recorder, and the individual's age category identified.

For age category identification I used the plumage and moult pattern criteria described and illustrated by Jonsson \& Tysse (1992). Summing up the ageing criteria, the adults arrive in prebasic moult in OctoberNovember, readily recognizable from remains of their alternate (breeding) plumage. After a few weeks they are in fresh basic (non-breeding) plumage with a white chin and foreneck and a pale bill with contrasting and well-marked dark tip and ridge of upper mandible. In the end of January/beginning of February the adults moult their remiges simultaneously and become flightless. This condition can easily be seen, as the birds frequently flap their wings during preening and after having swallowed a fish at the surface. In the course of March the growth of the remiges is completed, while at the same time an increasing number of alternate plumage body feathers appear, and the bill gradually darkens, starting with the middle and inner parts, leaving the tip paler than the rest. First year birds arrive in the autumn in their juvenile plumage, which is usually retained until January, when they moult into their first alternate plumage. First year birds retain much of their diffuse chin and foreneck patterns through their first basic plumage, as well as a pale bill with diffusely marked darker tip and upper ridge. In contrast to older birds, first year birds do not moult their remiges during winter. Birds in their second year appear on the wintering grounds with a plumage chiefly obtained during the summer. They look very dark above, their back and wings being noticeably darker than that of older birds and of first year birds, having almost no patterns, and the chin and foreneck are white. They retain the diffusely patterned bill of the first year birds. While adults retain a few black feathers with white spots from their alternate plumage among lesser coverts, no such feathers are found in second year birds. Yet, this is a character difficult to see under most field conditions. In late winter second year birds enter a pre-alternate moult, like birds in their third year and older, including simultaneous loss of flight feathers. From this stage on they can usually not reliably be told apart from adults.

Whenever more than one individual could be seen I paid special attention to social interactions, i.e., behaviour by one individual that seemed to release a response in an other. The manner of approaches, threats, attacks, and retreats were noted.

\section{RESULTS}

\section{Temporal distribution of social groups}

All juveniles observed in October and in most of November were accompanied by adults in groups ( $\mathrm{n}=18$ groups; Figure 1) consisting either of 2 adults and 1 juvenile $(n=14$ groups, $77.7 \%), 2$ adults and 2 juveniles $(n=2$ groups, $11.1 \%$ ) or 1 adult and 1 juvenile ( $n=2$ groups, $11.1 \%)$. Solitary first winter birds $(n=29)$ did not appear before end November and early December, and at this time adult-juvenile groups were no longer observed.
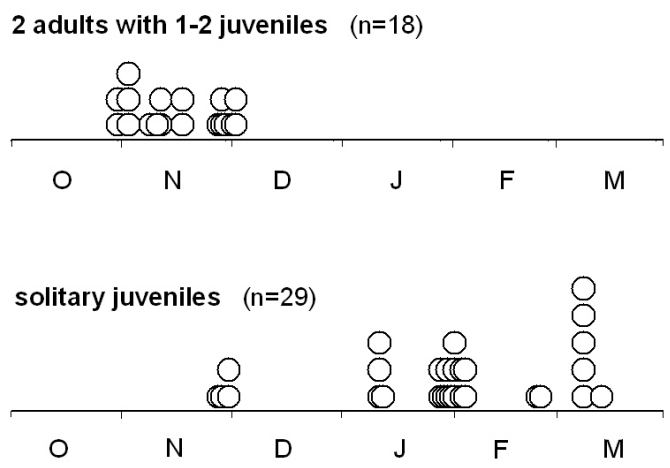

2 adults $(n=18)$

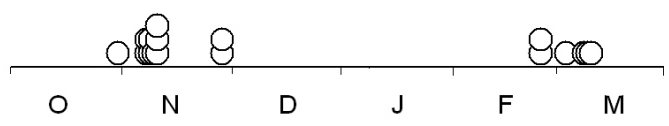

solitary adults $(n=95)$

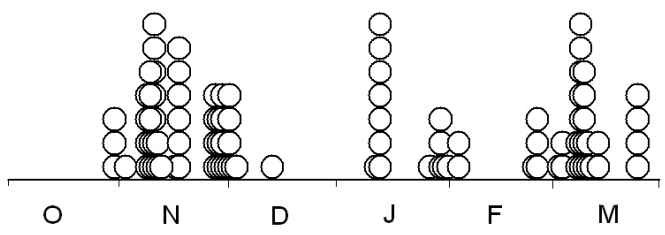

second winter birds $(n=20)$

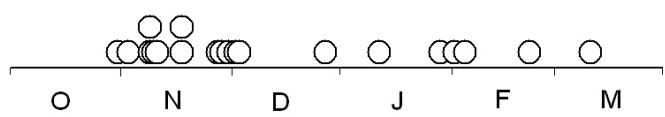

Figure 1. Seasonal distribution of social groups of Great Northern Divers in winter along the coast of Jæren. Each circle represents one group or solitary bird. 

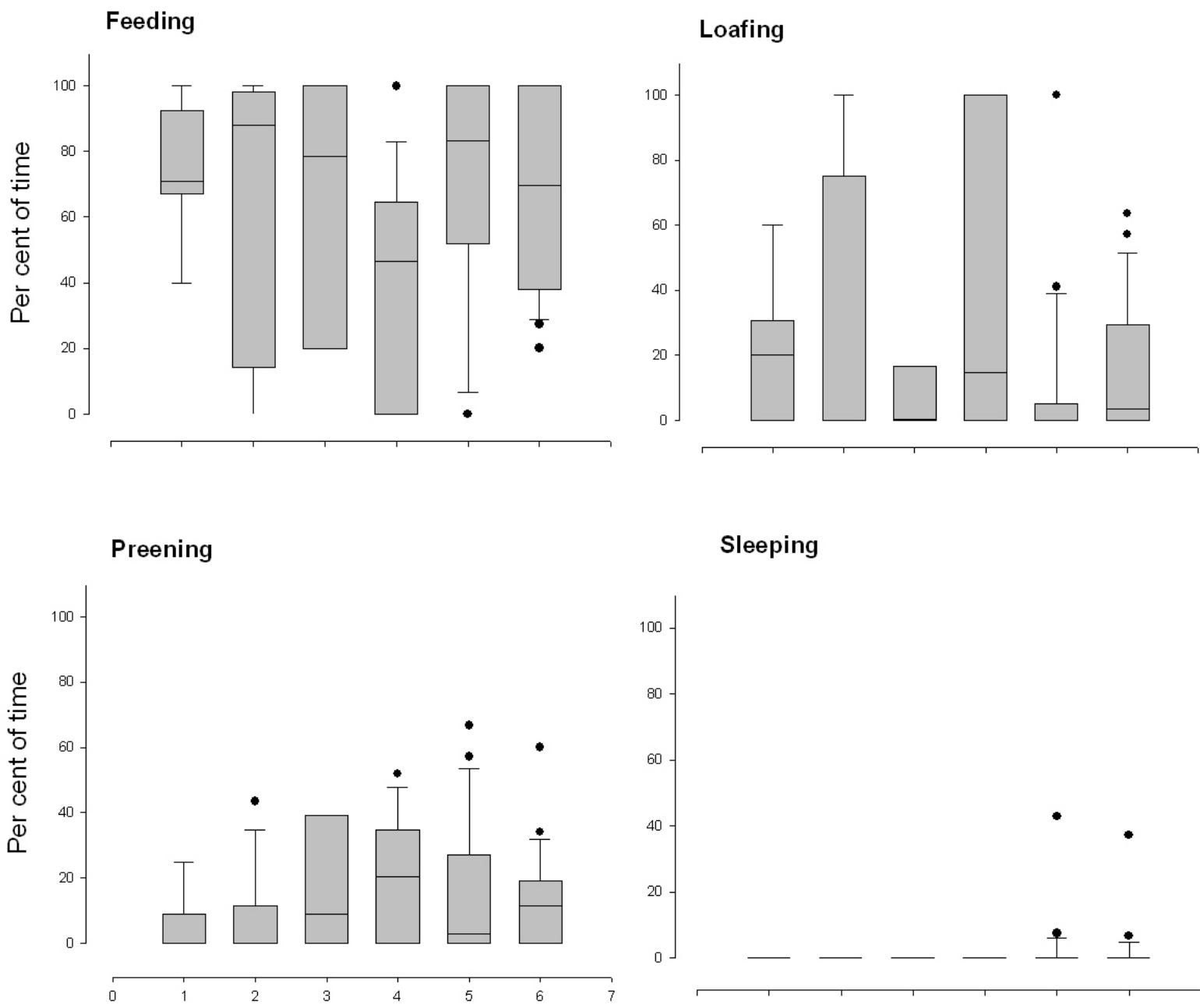

\section{Sleeping}
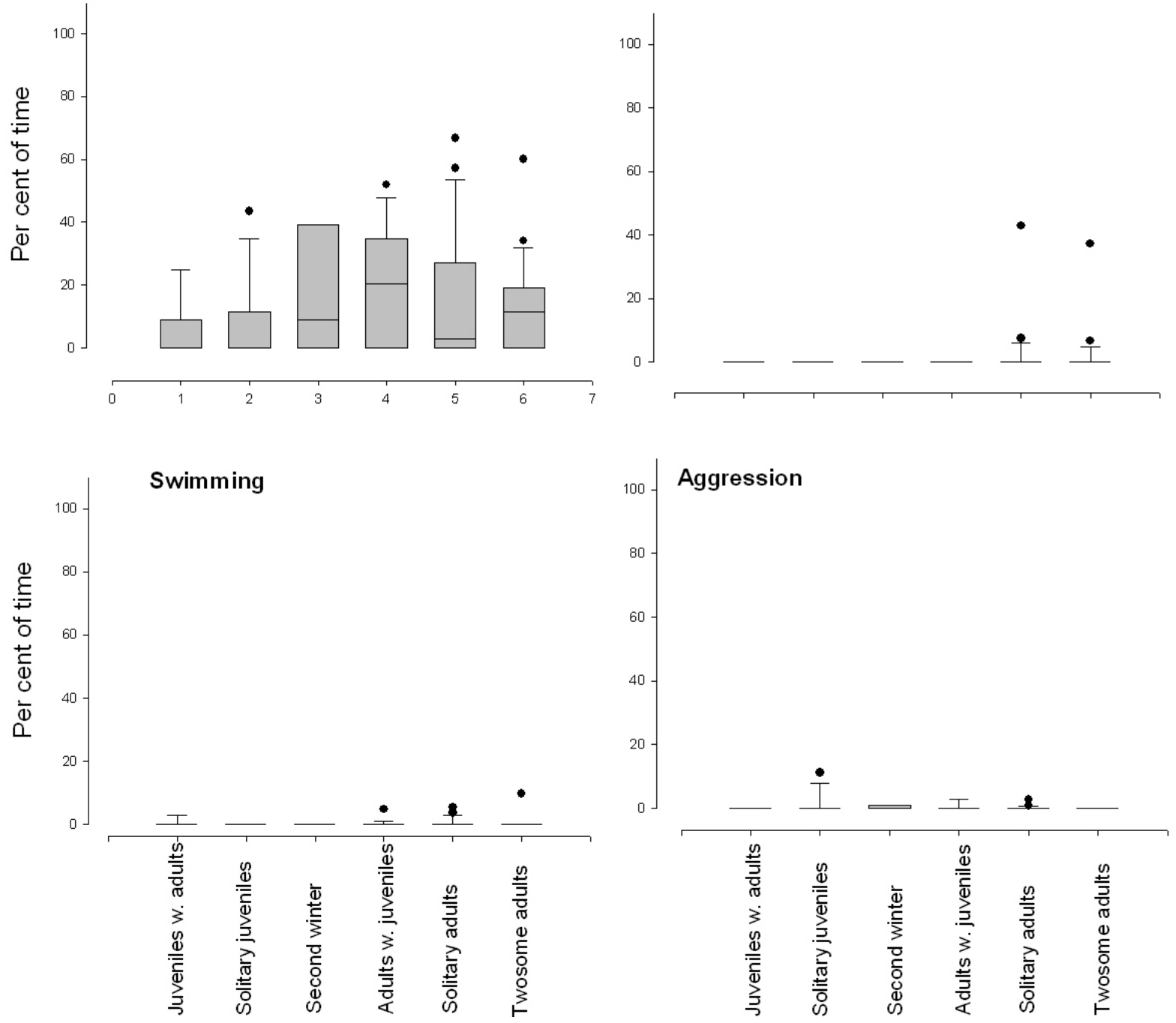

Figure 2. Time-activity budget of social categories of great Northern Divers along the coast of Jæren during winter. The boxes show first and third quartiles, horizontal line inside boxes indicate median values, whiskers show 95percentiles, and dots extremum values. The data are based on 30 minutes of focal-animal time budgets. Number of individuals in each social category: juveniles with adults 9 , solitary juveniles 12 , second winter birds 7 , adults with juveniles 18 , solitary adults 21 , twosome adults 20. 

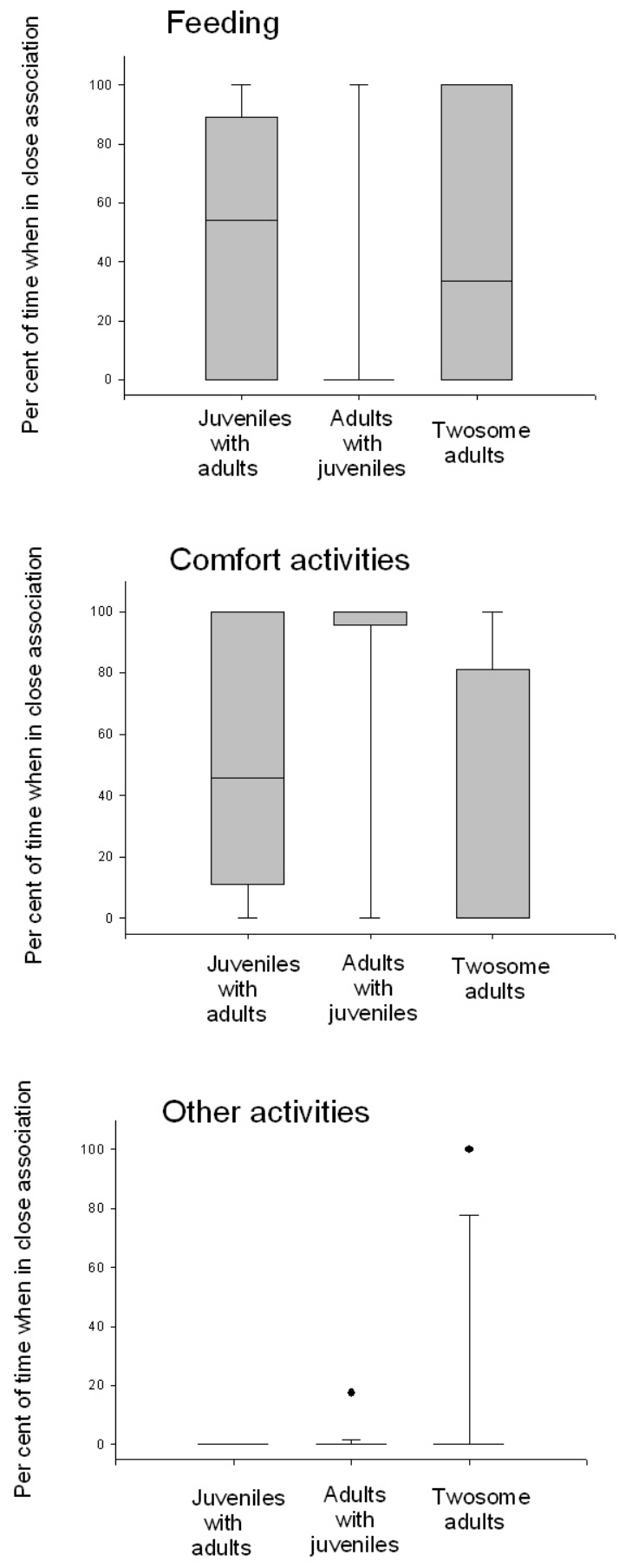

Figure 3. Activities of juvenile and adults, and of twosome adults, when in close proximity. "Comfort activities" are loafing, preening, and sleeping. "Other activities" include swimming, staying alert, aggression, and social interaction between group members. Other legends as in Figure 2.

Solitary adults $(n=95)$ and solitary second winter birds $(n=20)$ were seen throughout the winter. Twosome adults ( $n=18$ cases) showed a bimodal distribution, occurring in early autumn and late winter-early spring. None of the second winter birds were associated with any other individuals. The temporal distribution of social categories differed significantly over the winter (Kruskal-Wallis, $\chi 2=28.099, \mathrm{df}=4, \mathrm{p}<0.001)$, and when subject to nonparametric multiple comparison for unequal sample sizes (Zar 2010), juveniles accompanied by adults differed from solitary juveniles $(\mathrm{Q}=4.8161, \mathrm{k}=5, \mathrm{p}<0.001)$, from twosome adults $(\mathrm{Q}=3.1566, \mathrm{p}<0.05)$, and from second winter birds $(\mathrm{Q}=3.1164, \mathrm{p}<0.05)$. Also the temporal distribution of solitary adults differed from that of family groups $(\mathrm{Q}=3.6380, \mathrm{p}<0.005)$.

\section{Time budgets and vigilance}

The behavioural categories constituting the major parts of time budgets of Great Northern Divers regardless of age were feeding, loafing, and preening (Figure 2). The two latter allow birds to keep vigilant above the surface, while during feeding birds were in a surface position for only a few seconds at the time, except when handling large prey. Proportion of time spent feeding and non-feeding varied among the social categories of birds (one-way ANOVA on arcsine transformed individual proportions: $\mathrm{SS}=3.001, \mathrm{df}=5, \mathrm{MS}=0.600$, $\mathrm{F}=2.544, \mathrm{p}=0.034)$. Tukey tests showed that adults accompanying juveniles spent less time feeding that both twosome adults $(p=0,044)$ and solitary adults $(p=0.031)$. Juvenile birds associating with two adults spent $71 \%$ of the time feeding, while accompanying adults spent as little as $47 \%$ (median values), but these proportions were not statistically different (Tukey test, $\mathrm{p}=0.148$ ). To remove possible effects of year and locality, a pairwise comparison of adult-associated juveniles with one of its accompanying adults was performed ( $\mathrm{n}=8$ cases). In this comparison the adults did spend significantly less time feeding and more time non-feeding than the juveniles (paired sample T-test, $\mathrm{t}=5.121, \mathrm{df}=7, \mathrm{p}=0.001,2$-tailed).

Birds belonging to social groups (adults with juveniles, twosome adults) performed a variable part of their activities well separated (e.g. 100-300 m apart), but group members frequently united and spent time in close proximity (a few meter apart, or less). During time budget observations juveniles were recorded close to adults in median $62 \%$ of the time and adults close to juveniles $58 \%$ of the time (differences due to different sample sizes for individuals in association, Figure 3). While in close proximity, both juveniles and adults spent much of the time in comfort activities (loafing, preening, sleeping), whereas in contrast to the adults, the juveniles also spent a considerable part of the time feeding (Figure 4). While feeding in these situations the juveniles kept diving and surfacing only a few meters distance from where the adults were swimming.

Twosome adults spent $30 \%$ of the time (median) in close proximity. During this they spend about equal time in comfort behaviour and feeding (Figure 3 ). In two cases (November) the birds spent the time performing social behaviour, involving vocalizations, ritualized wing- 


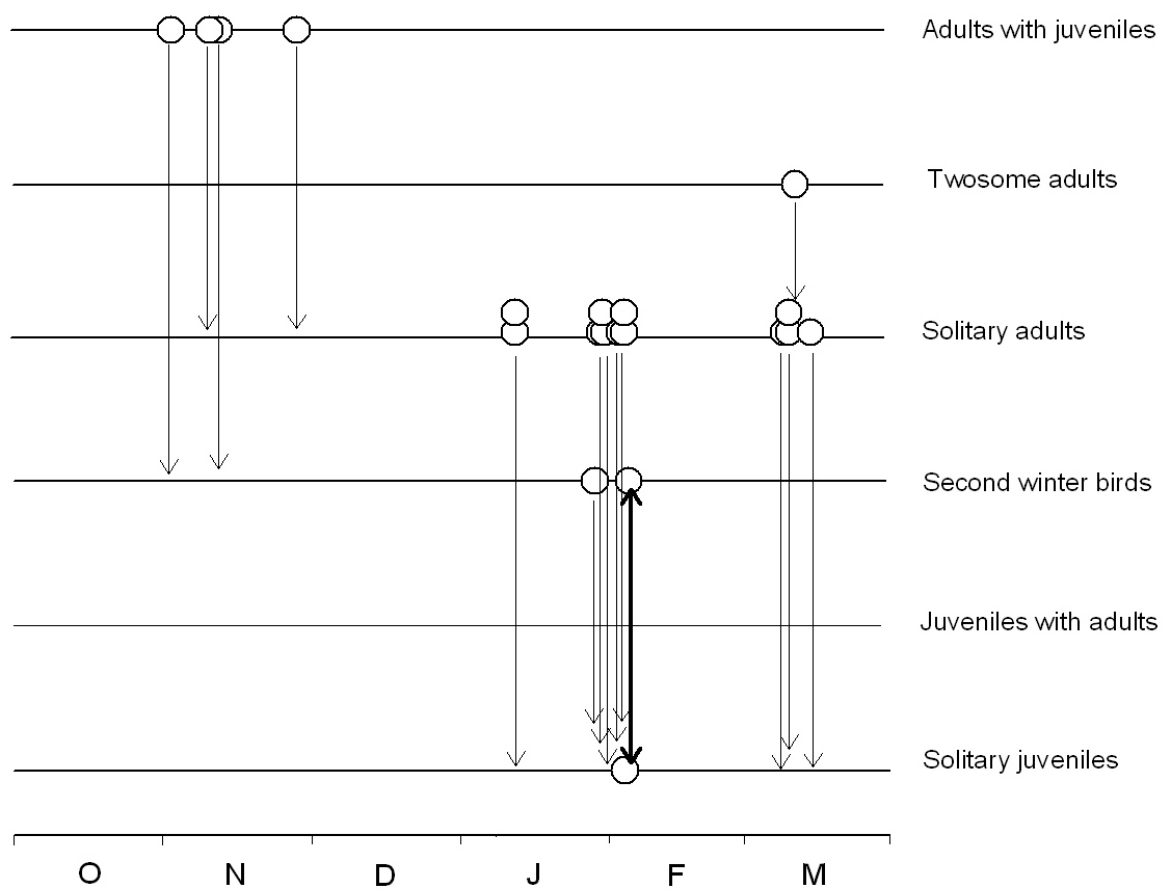

Figure 4. Intraspecific aggression in Great Northern Divers in winter on the coast of Jæren. Circles indicate individual aggressors. Arrows point at the social category of the individual at which the aggression was directed. Bold two-headed arrow indicates a case of aggression initiated by a juvenile bird against a second-winter bird, the latter retaliating and chasing away the juvenile.

flapping, ritualized diving, and close-distance circling of each other.

\section{Aggression}

Three variants of intraspecific aggression in Great Northern Divers were seen: attack, threat, and approach (McIntyre 1988). Attacking, the bird dived some tens of metres away from the opponent and charged from underneath. In threat the aggressor adopted a low posture, neck and head stretched forward pointing at the opponent while remaining stationary or swimming toward it. Usually, threat was given from a distance of about $20 \mathrm{~m}$ or shorter from the opponent. In approach, a bird would swim "determinedly" toward its opponent, neck somewhat curved and bill pointing slightly downward, giving the bird an enlarged impression.

Aggression from adults accompanying juveniles was shown against solitary adults and second winter birds (Figure 4). Both adult members of the group were involved in aggression against adults, while aggression against second winter birds involved only one of the adults. Solitary juveniles experienced aggression from solitary adults and solitary second winter birds. A case of twosome adults showing aggression against a solitary adult was also recorded. In all but one of the cases the opponent retreated. The exception was a second winter bird attacked by a solitary juvenile, but instead of withdrawing the second winter bird threatened the juvenile to retreat.
Opponents intimidated by threat and approach adopted a sleek, long-necked and low-floating posture followed by retreat, either in rapid surface swimming, long distance diving, or by flight, the latter in the form of rushing half airborne over the sea, along a stretch of about 50-60 m.

Adults accompanied by juveniles were dominant over solitary adults and second winter birds, and solitary adults and second winter birds over solitary juveniles (Figure 4). Thus, an aggressive dominance hierarchy seems to follow age.

\section{DISCUSSION}

This study shows that social behaviour of wintering Great Northern Divers, while changing over the winter, also differs between age classes. On arrival in autumn juveniles were associated with adults, and from the composition of these associations I interpret these groups to consist of a pair and their offspring, representing post migratory parental care. While group members were socially strongly attracted to one another, the adults of such groups engaged in aggressive actions toward neighbouring individuals, indicating territorial defence of an area used by the group for feeding. To what extent such areas represented permanent locations or merely a "mobile" area around the groups is not known, but confinement to certain locations did at least extend over a few 
consecutive days, as seen in a few cases where individual adults could be recognized by plumage patterns appearing on birds in prebasic moult. Family groups among wintering Great Northern Divers are considered to occur in autumn also in Shetland (Heubeck et al. 1993).

Prolonged parental care in which parents fend off food competitors might help juvenile Great Northern Divers to better food resources and a more undisturbed feeding during a period of their life when they need to improve their hunting skills, changing from catching freshwater fishes and invertebrates (Guðmundsson 1952, McIntyre1988, Evers et al. 2010) to preying on a much more diverse marine fish fauna. Juvenile Great Northern Divers spend more of their time hunting for food than do the older birds indicating a lower feeding efficiency in the young birds. Aggressive encounters show that dominance is linked to age, juveniles being lowest in dominance rank. By combined effort, however, two adults were seen to readily drive off single adults from the fishing grounds of juveniles. In most birds offspring are independent of their parents at fledging or shortly after. Offspring of cranes, and some large waterfowl, such as swans and geese, accompany their parents through their first winter (Alonso et al. 2004, Badzinski 2005), and by doing so may increase their survival and ultimately their reproductive fitness (Raveling 2000).

The putative family groups of Great Northern Divers seem to last only a few weeks, disappearing in early winter when juveniles and adults alike occur dispersed as solitary individuals. From then on aggression toward juveniles by older birds can be seen, and nothing indicates that juveniles get any parental support.

During the same time as family groups occur, a few cases have been seen of two adults together without any young accompanying them. Twosome adults have also occurred in late winter-early spring. These observations in autumn might represent post-migratory pairs with no young, and in spring perhaps old pair members joining up again some time before migration.

The social behaviour reported here apparently differs from that of non-breeding Great Northern Divers in North America. Here adults depart from the breeding grounds before juveniles (Evers et al. 2010), and it therefore seems unlikely that family groups continue to be united through migration and onto the wintering ranges. In Iceland and Greenland, where probably most of the Great Northern Divers wintering in European waters come from (Heubeck et al. 1993, Weir et al. 1996), adults and juveniles leave the breeding lakes simultaneously (Salomonsen 1967, Sjölander \& Ågren 1972).

In North America pair members migrate separately and winter in different locales, and males tend to arrive on the breeding lakes in spring earlier than the females (Evers et al. 2010), thus it seems unlikely that they pair up before leaving the wintering grounds. In Iceland Great Northern Divers are reported to arrive in pairs as the ice thaws from the lakes (Sjölander \& Ågren 1972). This supports the idea that twosome adults appearing from late winter on are likely to be mates. Also, twosome adults seen after autumn migration may indicate that pair members migrate together and winter fairly close to one another in spite of spending a solitary existence in mid winter. In Great Northern Divers pair bonds are known to last for many years (Evers et al. 2010).

Two factors are likely to cause social differences between European and American Great Northern Divers: (1) birds wintering in European waters breed in subarcticarctic regions (Iceland, Greenland) which have a much shorter season with birds arriving later and departing earlier than in studied populations much further south on the North American continent (Salomonsen 1967, Sjölander \& Ågren 1972, Evers et al. 2010) and (b) the European birds have to migrate across a large stretch of ocean with very limited staging possibilities, while in North America inland crossings offer freshwater lakes and rivers for staging, where food concentrations may even lead to flocking (McIntyre \& Barr 1983, McIntyre 1988).

No flocking was recorded in the present study, but flocks of Great Northern Divers can be seen at the coast of Jæren before and during spring migration (MarchMay; Tysse 1981.

The present interpretation of the social system of Great Northern Divers wintering on the SW coast of Norway, while plausible, rests on circumstantial evidence from social group composition and temporal distribution. Study of individually marked birds would be needed, and, if feasible, marking entire families with satellite transmitters on Icelandic breeding grounds.

Acknowledgements. I am grateful to Kåre Kyllingstad for help during the field work, and to Jim Paruk and an anonymous reviewer for comments on the manuscript.

Sammendrag. Sosial atferd hos ulike alderskategorier av overvintrende islom. Atferdsstudier av islom langs kysten av Jæren i vinterhalvåret viste at sosial atferd endrer seg over sesongen. Grupper bestående av to adulte fugler og en eller to ungfugler opptrådte etter ankomsten om høsten. De adulte fuglene i slike grupper var aggressive mot andre islommer i naboområdet, også mot andre adulte fugler. Tidlig på vinteren løste disse gruppene seg opp og fuglene spredte seg ut og ble solitære. Adulte fugler viste nå aggresjon også mot ungfugler. Fugler i sin andre vinter opptrådte alltid solitært, og disse var intermediære i dominans mellom adulte fugler og solitære ungfugler. Ungfugler som var sammen med adulte fugler brukte mer tid på fødesøk og mindre tid på puss og hvile enn de adulte som de holdt lag med. Gruppene med adulte og ungfugler tolkes som familiegrupper, der foreldrene beskytter ungfuglene i en tilvenningsfase til marint habitat med en annen fiskefauna enn i oppvekstområdene. To og to adulte islommer forekom både etter ankomsten om høsten og i forkant av vårtrekket, og dette antas å være eksempler på parsamhold under trekket. Islom i Nord-Amerika synes dels å ha andre sosiale forhold utenom hekketiden, idet ungfugl- og adulttrekket der foregår separat. 


\section{REFERENCES}

Alonso, J.C., Bautista, L.M. \& Alonso, J.A. 2004. Familybased territoriality vs flocking in wintering Common Cranes Grus grus. J. Avian Biol. 35: 434-444.

Altmann, J. 1974. Observational study of behavior: sampling methods. - Behaviour 49: $227-267$.

Badzinski, S.S. 2005. Social influences on Tundra Swan activities during migration. Waterbirds 28: 316-325.

Byrkjedal, I., Eldøy, S., Grundetjern, S., Løyning, M.K. 1997. Feeding association between Red-necked Grebe Podiceps griseigena and Velvet Scoters Melanitta fusca in winter. Ibis 139: 45-50.

Byrkjedal, I., Breistøl, A., Mjøs, A.T. \& Strann, K.-B. 2000. Winter habitat of White-billed and Great Northern Divers on the coast of Norway. Ornis Norv. 23: 50-55.

Daub, B.C. 1989. Behavior of Common Loons in winter. J. Field Ornithol. 60: 305-311.

Evers, D.C., Paruk, J.D., McIntyre, J.W. \& Barr, J.F. 2010. Common Loon (Gavia immer). The Birds of North America Online (A. Poole, ed.) Ithaca: Cornell Lab of ornithology (http:bna.birds.cornell.edu/bna/ species/313).

Ford, T.B. \& Gieg, J.A. 1995. Winter behavior of the Common Loon. J. Field Ornithol. 66: 22-29.

Guðmundsson, F. 1952. Íslenskir fuglar I. Himbrimi (Colymbus immer Brünn.). Náttúrufræðingurinn 22: 44-45.

Heubeck, M., Richardson, M.G., Lyster, I.H.J. \& McGowan,
R.Y. 1993. Post-mortem examination of Great Northern Divers Gavia immer killed by oil pollution in Shetland, 1979. Seabird 15: 53-59.

Jonsson, L. \& Tysse, T. 1992. Lommar. Vår Fågelvärld, Suppl. No. 15.

McIntyre, J.W. 1978. Wintering behaviour of Common Loons. Auk 95: 396-403.

McIntyre, J.W. 1988. The Common Loon: spirit of the northern lakes. Univ. of Minnesota Press, Minneapolis.

McIntyre, J.W. \& Barr, J.F. 1983. Pre-migratory behavior of Common Loons on the autumn staging grounds. Wilson Bull. 95: 121-125.

Raveling, D.G. 2000. Reproductive success and survival in relation to experience during the first two years in Canada Geese. Condor 102: 941-945.

Salomonsen, F. 1967. Grønlands fugle. Munksgaard, Copenhagen.

Sjölander, S. \& Ågren, G. 1972. Reproductive behaviour of the Common Loon. Wilson Bull. 84: 296-308.

Tysse, T. 1981. Vinterbestanden av lom og dykkere i Rogaland. Falco 10: 4-24.

Weir, D.N., McGowan, R.Y., Kitchener, A.C., McOrist, S. \& Heubeck, M. 1996. Effects of oil spills and shooting on Great Northern Divers which winter in Scotland. Dansk Orn. Foren. Tidsskr. 90: 29-33.

Zar, J.H. 2010. Biostatistical analysis. Fifth edition. Pearson Education, Upper Saddle River, NJ.

Received 11 March 2011. Accepted 16 May 2011 